\title{
Evaluating Perceived Quality of B-School Websites
}

\author{
N. Elangovan \\ Assistant Professor, Department of Management Studies, Christ University, Bangalore
}

\begin{abstract}
Websites are a window for the world for looking in most of the Information and a gateway for many activities. Websites are not only a necessity but also mandatory for B-Schools. A B-School Website serves as portal to all stakeholders in addition to being an information placeholder. The Websites serves from being an administrative tool to a Learning Management system. The utility and the effectiveness of website depend on the quality of the service it provides to the surfer. A study was undertaken to survey the various features of a BSchool Website that could serve as a Quality Function Deployment (QFD) touchstones. In addition, the influence of perceived quality on the user satisfaction was also studied. A focus group of B-School Students evaluated the Websites and scored a checklist cum questionnaire. The results highlight the most frequently found features and the least found features of a B-School Website. The factors that are important for creating a quality website are also found. This study will help the B-school administrators and the Website designers to create a quality and satisfying Websites.

Keywords: B-School, Website features, WebQual
\end{abstract}

\section{Introduction}

The Internet has become ubiquitous in the modern world. As Carr (2003), in his article, "IT Doesn't Matter" argues that the strategic importance of information technology in business has diminished as IT has become more commonplace, standardized and cheaper. The advancement in the technology and its utility makes it very difficult for a business to survive without a website. Businesses without a website in today's date tend to lose large number of its potential customers. Therefore having a web site is not just a commodity for businesses nowadays, but a must. Need for quality website for schools, universities and other educational institutions is constantly increasing, as online technologies become a bigger part of the educational process as well as decision support for prospective students in selecting their place of study. The website also reflects the professional image of the institution. This makes it important for institutions to work on making their web sites attractive, informative, student -friendly and easy to navigate and with up-to-date technology, so surfers can easily locate what they are looking for. A website that creates positive influence in the users gets more exposure by hits created by the new users and returning users. The positive influence is created by different features embedded in the Website and the quality of such features and the services provided.

This study focuses on enumerating the features of a Business School Website using a checklist. This will highlight the most frequently found features and the ones found only in a few B-Schools Websites. However, the outcome of the study can rank the most important features required in the B-School Websites. This also throw light on the gap in designing the desirable features in a website that can really create an experience to the surfer. In addition, this study also measures the Website quality using the WebQual-4 parameters and helps to understand the factors that influence the user satisfaction in the Website. The outcome of this study will help the B-Schools in designing a website with features that will provide the users with various information and utilities, thereby making the Website a gateway to all the stakeholders and create a satisfaction in them.

The structure of the paper is as follows. The next section describes the theoretical background that supports this study and describes background of the development of WebQual. In the third section the framework and the methodology of the study are explained. In the fourth section, the results of the data analysis are presented. In the fifth section the outcome of the study and its implications are discussed. The last section draws conclusions and makes recommendations for future work.

\section{Review of Literature}

Zhang and Von Dran (2002) noted that the website functions as a 'window' through which users have their initial interaction with the organisation. With the advancement in technology, sophistication of customers' needs and the environment becoming more competitive, the focus is towards the quality of the web site. Liang and Lai (2002) have found that the likelihood and the frequency of visitors to the website are positively correlated to the web site quality. A tool for evaluating the website quality is also required for number of reasons, such as a reviewing tool to the hosting organizations and to novice web developers as quality touchstones in order to create usable Websites. 
The concept of quality is consisting of many criteria: quality of service perspective, a user perspective, a content perspective or indeed a usability perspective (Jati \& Dominic, 2009). However, for software testers Webmasters, Web applications developers, and Website quality assurance managers need tools and methods that are technical and spell the specification for engineering the Website. Kopcso, Pipino and Rybolt, (2001) categorized the tools of website quality into 6 groups: (a) works that present prescriptions for good web site design, (b) academic research that has addressed design issues, (c) work that focuses on the end users' perceptions and evaluations of the quality of a web site such as WebQual, (d) work that examines communication effectiveness and benefits delivered by commercial sites, (e) investigations into the applicability of data quality research in the traditional database and data warehouse contexts to a web environment and (f) commercial sites, such as gomez.com, that rate other sites.

Bressolless and Nantel (2004) categorised the quality measurement tools on the perspective of researchers and practitioners. The researcher's tools are again grouped into behavioural and attitudinal measures. Behavioural measures focus on the measurement of the commercial activity of the site: number of clicks, number of unique visitors or conversion rate of new visitors, analysis of log files, analysis of navigation protocols or ongoing verbalization of consumers in a navigation situation. Attitudinal measures are traditional measurement scales that evaluate perceptions of consumers or that rely on professional experts to measure these perceptions. Under this category falls two approaches. The first one generally based on experts' evaluation or interstitial surveys seem more common among practitioners. The second one, more grounded in psychometric theory, is more prevalent among scholars. Bressolless and Nantel are of the opinion that practitioners have adopted various approaches to measure perceptions of quality or efficacy of commercial websites: questioning consumers after their purchase (Bizrate.com, Directpanel.com), or using professional experts to evaluate sites (Gomez.com). However, they feel that these methods have problems of conceptualization of constructs or the validity and reliability of the measures used.

Bressolles and Nantel (2008) described and compared various tools used for evaluation of Websites. They compare:

a) EtailQ, developed by Wolfinbarger and Gilly (2003) that included 14 items divided into 4 dimensions (design, customer service, reliability/compliance with commitments and security/privacy),

b) Webqual-4 developed by Barnes and Vidgen (2003), composed of 22 items on 3 dimensions (quality of information, quality of interactivity /confidence and empathy, and usability of the site / usability and design),

c) Sitequal developed by Yoo and Donthu (2001), that included 9 items distributed over 4 dimensions (ease of use, design, processing speed and security) and

d) NetQual (Bressolles, 2006).

There are other studies that utilise the popular TAM based models to evaluate the quality, and to predict the usage of the website (Loiacono, Watson, \& Goodhue, 2002).

Context specific evaluation of quality has been done on Websites. The table -1 shows the streams of research in different areas. Institutional web sites have become a major source of academic information to the outside world, so it is essential for an institution to have a strong web presence. Website design for academic institutions offers an insight into their and acts as a portal for all its stakeholders. The primary users of an academic websites are students. They look for information at various levels: a prospective student is interested in understanding what the institution provides, its programmes, infrastructure, knowledge resources etc. An enrolled student look at the website for the course details, calendar and schedules, events, connects to library and learning management system etc. A past student visits to have a network of alumni and track his alma mater. The faculty use a website to disseminate information and learning material to the students. They host their material for distribution and even discuss with students on blogs. The promoters and administrators use website as a promotion tool for internal and external communication. Legal system requires B-Schools to disclose certain mandatory information on their websites. Parents keep track of their ward progress at the school by looking at their grade sheets and feedbacks. An employer connects to a B-School website to look for prospective candidates.

\subsection{About Webqual-4 tool}

WebQual is basically used as an instrument for assessing user perceptions of the quality of Web sites. WebQual is based on quality function deployment (QFD) and is different from other studies that emphasize on the site characteristics or features (Kim \& Eom 2002). Therefore, the instrument measures the qualities subjectively. However, it can be coded and can be analysed using quantitative techniques. Previous applications of WebQual include UK Business School sites, Internet bookshops, and a longitudinal study of small to medium sized enterprises in the market intelligence sector (Barnes \& Vidgen, 2001a). 
Table 1. Various contexts of Website Quality evaluation

\begin{tabular}{|c|c|}
\hline Context & Authors \\
\hline Academic web sites & Barnes and Vidgen (2000); Gullikson et al (1999); Tate et al (2007) \\
\hline Small companies & Barnes and Vidgen (2001b); Thelwall (2000) \\
\hline Online auction houses & Barnes and Vidgen $(2001 \mathrm{c})$ \\
\hline Internet bookshops & $\begin{array}{l}\text { Barnes and Vidgen (2001a); } \\
\text { Barnes and Vidgen (2002) }\end{array}$ \\
\hline Airline industry & Shchiglik et al (2003) \\
\hline e-Governance & Alanezi, Kamil and Basri (2010); Barnes and Vidgen (2002) \\
\hline e-Commerce websites & $\begin{array}{l}\text { Longstreet (2010); Loiacono et al (2002); Gehrke and Turban } \\
\text { (1999); Carlson, Voola, and Sinnapan (2003); Long and McMellon } \\
\text { (2004); Yoo and Donthu (2001); Webb and Webb (2004) }\end{array}$ \\
\hline Hotel Website & Sigala and Christou (2006) \\
\hline B2C Cosmetic Website & Durova and Amin (2009) \\
\hline Stock Exchange & Tarigan (2008) \\
\hline Museum Website & Fotakis, Th. \& Economides (2008) \\
\hline Banking & Arientawati (2010) \\
\hline WAP Websites & Barnes, Liu, and Vidgen (2001) \\
\hline $\begin{array}{l}\text { Forum on Strategic Management Knowledge } \\
\text { Exchange (FSMKE) Web site }\end{array}$ & Barnes and Vidgen (2003) \\
\hline Public accounting (PA) firms & Fink and Nyaga (2009) \\
\hline Public www & Bauer and Scharl (2000) \\
\hline Travel services & Nusair and Kandampully (2008) \\
\hline Categorise the features & Huang, Le, Li, and Gandha (2006) \\
\hline Apparel Websites & Kim and Stoel (2004) \\
\hline Comparison of tools & Bressolles and Nantel (2008) \\
\hline Cross-cultural aspects of web sites & Kim and Lee (2006) \\
\hline E-Loyalty in e-commerce Websites & García et al (2005) \\
\hline
\end{tabular}

While WebQual 1.0 was strong on information quality, it was weak on interaction. Similarly, where WebQual 2.0 emphasized interaction quality it lost some of the information quality richness of WebQual 1.0. WebQual 3.0 brings together the information quality of WebQual 1.0 and the interaction quality of WebQual 2.0. Quality is viewed in three dimensions: Information quality, Interaction Quality, and Site Design Quality. The instrument is tested in the domain of online auctions (Amazon, eBay, and QXL) and involved a high degree of interaction of the subjects and the web sites evaluated (Barnes \& Vidgen, 2001a). Replacing site quality with usability, WebQual- 4.0 emphasizes the user and his/her perceptions rather than those of the designer. WebQual has developed into the next version and today known as eQual-5 and used as an instrument for assessing user perceptions of the quality of e-commerce Web sites (Barnes \& Vidgen, 2005).

\section{Methodology}

Webqual is usually used to analyze website among purchase or commercial website, education and internet banking website. In this study, the WebQual method is used to evaluate the quality of the B-School website and the overall satisfaction of the users. Under this model, the quality of the website is measured for the Service quality, Usability and the Information quality. The model is depicted in Figure below.

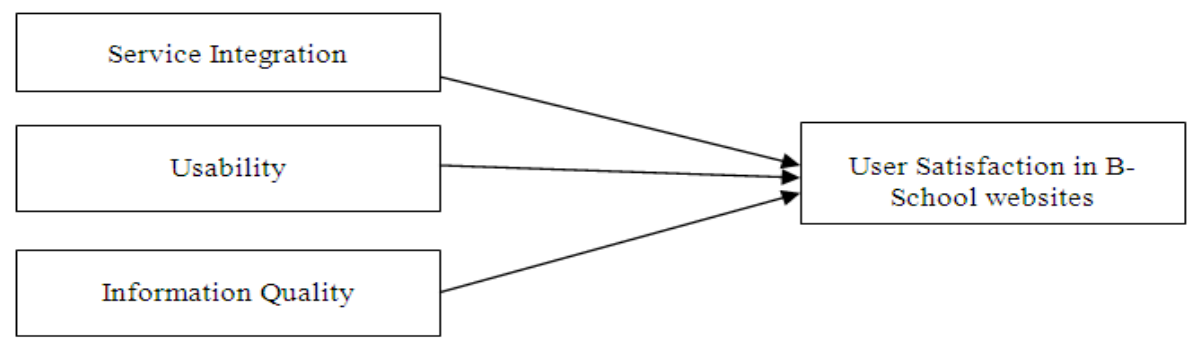

In the WebQual -4, Barnes \& Vidgen (2005) explained that the dimension of Information quality is adopted from the mainstream Information System (IS) research. This construct is built on literature focused on information, data and system quality, including Bailey and Pearson (1983), Strong et al. (1997) and Wang (1998). The dimension of Interaction and service quality are sourced from marketing, e-commerce and IS service quality research. This construct is built on the SERVQUAL (Parasuraman, 1995, Zeithaml et al. 1990, 1993) and IS SERVQUAL (Pitt et al. 1995, 1997, Kettinger \& Lee 1997, Van Dyke et al. 1997) and is based on the Shostack's (1985) definition of a service encounter as "a period of time during which a consumer directly 
interacts with a service". The dimension of Usability is drawn from literature in the field of human computer interaction (Davis 1989, 1993, Nielsen 1993) and Web usability (Nielsen 1999, 2000, Spool et al. 1999).

\subsection{Instrument Development}

The instrument is designed in two parts, Section A and Section B. The section A is a check list of features of a B-School Website. This was developed by exhaustively collecting the features of various B-School Websites and consolidating them. 34 features were identified to be present in B-School Websites and these were devised into a check list. This checklist will score the availability of the listed features in each of the B-School Websites taken for the study. The section B of the instrument is adopted from the WebQual-4. A user's perception of a "good" information system would be a system where a user is satisfied with the qualities of the website. The previous researches suggest the dimensions of WEBQUAL are predictive of user satisfaction and the intention of user to reuse the website (Barnes \& Vidgen, 2002; Loiacono et al, 2002).

There are three independent variables in the standard WebQual, where the dimension usability, information quality and service interaction quality are measured by 23 questions. Besides that, this study also has one dependent variable, which is user satisfaction. Three items relates more to a commercial website where there will be transaction of products or service. Therefore these item are removed since the B-School websites do not transact any commercially valuable goods are services. Two new items are included to reflect the technical service quality of the websites such as; 'The web page loads faster', and 'Website is compatible with all platforms' (Table 2). The measurement scale use in this study is five-point Likert scale. Respondents will be asked to rate the website for each quality using a scale ranging from 1 (strongly disagree) to 5 (strongly agree).

\subsection{Sample Design}

The business schools in India that are offering postgraduate programme business management are taken as the population for the study. There are over $4000 \mathrm{~B}$-Schools in India of which 3,500 management institutes alone approved by the AICTE, of which 3,000 offer MBA programmes and 500 offer diplomas ${ }^{1}$. Business India BSchool Survey ${ }^{2}$ listed around 350 top institutions and their URL name. Having this database as a representative population, the list is used as the sample framework. Within this sample framework, the of B-School website were randomly selected. Totally $240 \mathrm{~B}-$ School websites were identified and assigned to a group of students.

The participants of the focus group for the study were selected students of postgraduate programme of Business Administration (MBA). The students had to browse through the website and verify the items in a checklist. After they have thoroughly explored and experienced the web pages, they were provided with a questionnaire that elicited their opinion and perception on the quality of the website. Only 206 usable responses were received which are used for the further analysis.

\section{Data Analysis and Results}

This chapter shows the descriptive results of data collection and presents the findings of data analysis associated with research hypotheses. It contains four sections of empirical results. The first section is the descriptive statistics of the features of the website. The numbers of B-School websites that have each of the features are consolidated and are presented in a table. The second section is the results of the WebQUal measures showing their mean and the distribution. The third section is the reliability tests of measurement scales. It consists of the evaluations of the coefficient alpha. The fourth section depicts the relationship between the constructs using multivariate regression analysis.

First the responses that were received are coded and entered into a spreadsheet. For the part-A of the questionnaire, which is a checklist that evaluates the availability of various features in the B-School website, the values is scored as one for features available and zero for features not available. The part-B of the questionnaire, which measures the website quality on a five-point Likert scale is coded as ' 1 ' for strongly disagree, ' 2 ' for disagree, ' 3 ' for Neutral, ' 4 ' for agree and ' 5 ' for strongly agree.

\subsection{Features of the B-School Websites}

The respondents were first asked to browse through the given website and were asked to score a checklist for availability and non-availability of the listed features. The results are consolidated and are presented in table 2 .

\footnotetext{
${ }^{1}$ http://indiatoday.intoday.in/story/delhi-branded-capital-of-fake-business-schools/1/151794.html accessed on May 15,2013

${ }^{2} \mathrm{http} / / /$ www.seaastandards.org/bschools2011/Alphabetical\%20List.pdf accessed on February 20, 2013. 
Table 2 - Frequency Table for availability of features in the website

\begin{tabular}{|c|c|c|c|}
\hline S.No. & Website Features & $\begin{array}{c}\text { Frequency } \\
\mathbf{N}=206\end{array}$ & Percent \\
\hline 1 & About The Institute & 206 & 100.0 \\
\hline 2 & Contact Details & 192 & 93.2 \\
\hline 3 & Admission Details & 186 & 90.3 \\
\hline 4 & Program & 171 & 83.0 \\
\hline 5 & Placement & 171 & 83.0 \\
\hline 6 & Application Download & 169 & 82.0 \\
\hline 7 & Events And Programme & 169 & 82.0 \\
\hline 8 & News And Diary & 161 & 78.2 \\
\hline 9 & About The Management & 159 & 77.2 \\
\hline 10 & Courses & 154 & 74.8 \\
\hline 11 & Publications & 148 & 71.8 \\
\hline 12 & Alumni Connections & 148 & 71.8 \\
\hline 13 & Infrastructure Details & 145 & 70.4 \\
\hline 14 & Faculty Directory & 136 & 66.0 \\
\hline 15 & Site Map & 128 & 62.1 \\
\hline 16 & Departments & 125 & 60.7 \\
\hline 17 & Research Centre & 118 & 57.3 \\
\hline 18 & Academic Calendar & 112 & 54.4 \\
\hline 19 & Students Community & 111 & 53.9 \\
\hline 20 & Repository & 110 & 53.4 \\
\hline 21 & Details of Office And Service & 107 & 51.9 \\
\hline 22 & Industry Connect & 100 & 48.5 \\
\hline 23 & Examination And Results & 99 & 48.1 \\
\hline 24 & Mail Services & 94 & 45.6 \\
\hline 25 & Accreditation Information & 92 & 44.7 \\
\hline 26 & Life At Campus & 91 & 44.2 \\
\hline 27 & Curriculum & 90 & 43.7 \\
\hline 28 & Search Engine & 90 & 43.7 \\
\hline 29 & Location Map & 89 & 43.2 \\
\hline 30 & Staff Directory & 88 & 42.7 \\
\hline 31 & Link To Library Resources & 71 & 34.5 \\
\hline 32 & Feedback System & 52 & 25.2 \\
\hline 33 & Web2.0 & 40 & 19.4 \\
\hline 34 & Link To Learning Management System & 34 & 16.5 \\
\hline
\end{tabular}

The table shows the number of websites which has the listed features. All the websites (100\%) are generous with complete information saying about the institution. Around $90 \%$ of the websites have the admission details in them. In general around $80 \%$ of the websites furnish the information regarding the program, a link to application download, details about the events and program, news \& diary, placement information and the contact details. On Average 50 to $79 \%$ of the websites provide information About The Management, Academic Calendar, Alumni Connections, Students Community, Repository, Site Map, Details of Office And Service, Departments, Courses, Faculty Directory, Research Centre, Publications. Around 20 to $49 \%$ of the websites carry information's like Location Map, Curriculum, Staff Directory, Link to Library Resources, Examination and Results, Life at Campus, Industry Connection, Accreditation Information, Mail Services, Search Engine, Feedback System. Only 19.4\% of the websites provide Web2.0 feature and $16.5 \%$ of the websites provides a link to their learning management system (Table 2).

\subsection{Website quality parameters}

The perception on the various quality parameters of the B-School website was obtained on a five-point Likert Scale of agreeableness. On a scale of 1 to 5 and mid value of 3, the mean values of the items are interpreted to be high or low. The results are presented in the table 3. The participants report that the B-School websites are better in terms of ease to learn, ease to navigate, ease to use, faster loading and clear interaction. The participants feel that the websites are low in security, personalization and in providing a sense of community. However the overall opinion on the B-School websites were Satisfactory 
Table 3 - Descriptive statistics of the WebQual Measures

\begin{tabular}{|c|c|c|c|c|c|c|}
\hline & Z & $\underset{\Xi}{\stackrel{\Xi}{\Xi}}$ & 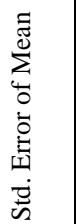 & 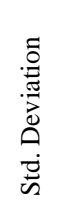 & 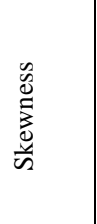 & 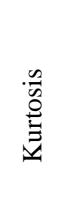 \\
\hline Easy to learn & 206 & 3.65 & .068 & .970 & -.643 & .312 \\
\hline Interaction clear & 206 & 3.50 & .068 & .977 & -.494 & .198 \\
\hline Easy to Navigate & 206 & 3.55 & .064 & .919 & -.697 & .515 \\
\hline Easy to use & 206 & 3.55 & .071 & 1.024 & -.669 & .330 \\
\hline Attractive appearance & 206 & 3.35 & .070 & 1.000 & -.215 & -.299 \\
\hline Appropriate design & 206 & 3.43 & .066 & .948 & -.326 & -.279 \\
\hline Competency & 206 & 3.25 & .062 & .890 & -.173 & -.586 \\
\hline Positive experience & 206 & 3.42 & .063 & .911 & -.275 & -.033 \\
\hline Accurate & 206 & 3.32 & .064 & .923 & -.255 & -.160 \\
\hline Believable & 206 & 3.20 & .065 & .934 & -.770 & .161 \\
\hline Timely & 206 & 3.33 & .071 & 1.016 & -.446 & -.146 \\
\hline Relevant & 206 & 3.41 & .068 & .972 & -.284 & -.168 \\
\hline Understandable & 206 & 3.40 & .070 & 1.001 & -.407 & -.172 \\
\hline Detail & 206 & 3.23 & .066 & .948 & .014 & -.268 \\
\hline Format & 206 & 3.25 & .066 & .953 & -.310 & -.032 \\
\hline Secure & 206 & 2.97 & .056 & .799 & -.113 & -.125 \\
\hline Personalised & 206 & 2.99 & .061 & .881 & .072 & -.009 \\
\hline Sense of community & 206 & 2.99 & .065 & .934 & .247 & -.268 \\
\hline Communicate & 206 & 3.34 & .064 & .912 & -.310 & -.051 \\
\hline Loads faster & 206 & 3.51 & .062 & .887 & -.488 & .289 \\
\hline Compatible & 206 & 3.33 & .060 & .854 & -.217 & .467 \\
\hline Overall satisfaction & 206 & 3.61 & .059 & .847 & .122 & -.692 \\
\hline
\end{tabular}

Cronbach alpha is the general standard for measuring a group indicator from second or many variables. This value range from 0 to 1 , where value of high alpha shows high reliability between the indicators (Boudreau, Gefen, \& Straub, 2001). As a rule of thumb, the value of cronbach's alpha over 0.7 is adequate for the research of social science. The reliability of the three constructs used in the study is presented in the table- 4 . The result show that the cronbach's alpha values of the WebQual variables are all above 0.742 , which are above the minimum acceptable level. This shows that the multi item measures reliably measure the intended construct.

Table 4 - Reliability Statistics for the WebQual Variables

\begin{tabular}{|l|l|l|l|}
\hline Construct & Cronbach's Alpha & N of Items & \multicolumn{1}{c|}{ Variables } \\
\hline & & & Easy To Learn \\
& & & Interaction Clear \\
& & & Easy To Navigate \\
& & & Easy To Use \\
& & & Attractive Appearance \\
& & & Appropriate Design \\
& & & Competency \\
& & & Positive Experience \\
\hline & & & Accurate \\
& & & Believable \\
Information & & & Timely \\
Quality & & & Relevant \\
& & & Understandable \\
& & & Detail \\
& & & Format \\
\hline Service & & & Secure \\
Integration & & & Personalized \\
& & & Sense Of Community \\
& & & Communicate \\
& & & Loads Faster \\
& & & Compatible \\
\hline
\end{tabular}

Before doing an inferential study of the WebQual model, the correlations between the constructs are verified. The linearity of the relationship between dependent and independent variables represents the degree to which the change in the dependent variable is associated with the independent variable. If the constructs have a lower correlation, the regression equation will be inconclusive. This will mean that the independent constructs will have high discriminance and each will explain the dependent variables in a different degree and perspective. 
Similarly, high correlation (generally 0.90 and higher) between variables will result in multicollinearity that will reduce any single independent variable's predictive power by the extent to which it is associated with the other independent variables. A value between 0.3 and 0.7 will result in a predictable model with a good fit.

Table 5 - Correlations

\begin{tabular}{|l|l|l|l|}
\hline & Usability & Quality & Service \\
\hline Usability & 1 & $.490^{* *}$ & $.443^{* *}$ \\
\hline Quality & $.490^{* *}$ & 1 & $.446^{* *}$ \\
\hline Service & $.443^{* *}$ & $.446^{* *}$ & 1 \\
\hline
\end{tabular}

Table 5 presents the correlation between the three independent variables used in the study. The values lie between 0.443 and 0.490 with a significant value of $\mathrm{p}<0.001$, which shows a significant but moderate correlation perfectly suitable for the regression analysis.

The constructs, service interaction, Information quality and usability are next entered into regression with overall satisfaction as dependent variable. The results of the regression analysis are presented in the table 6 . All the three dependent variable are found to significantly explain the variance in the overall user satisfaction. Using the beta coefficients, it can be understood that the usability is the most important factor that influence the satisfaction. Followed to that Service interaction is next important factor and Information quality is also having an influence on user satisfaction. The model is also found to be significant and fit to the data very well. The model R-Square value is 0.444 , which means that the three independent variables explain $44.4 \%$ of the variance in the dependent variable. This shows that a good amount of user satisfaction can be influenced by managing the usability, service interaction and information quality. The rest of the user satisfaction can be understood to be created by unknown factors or by variables not included in this study.

Table 6 - Regression analysis of the WebQual

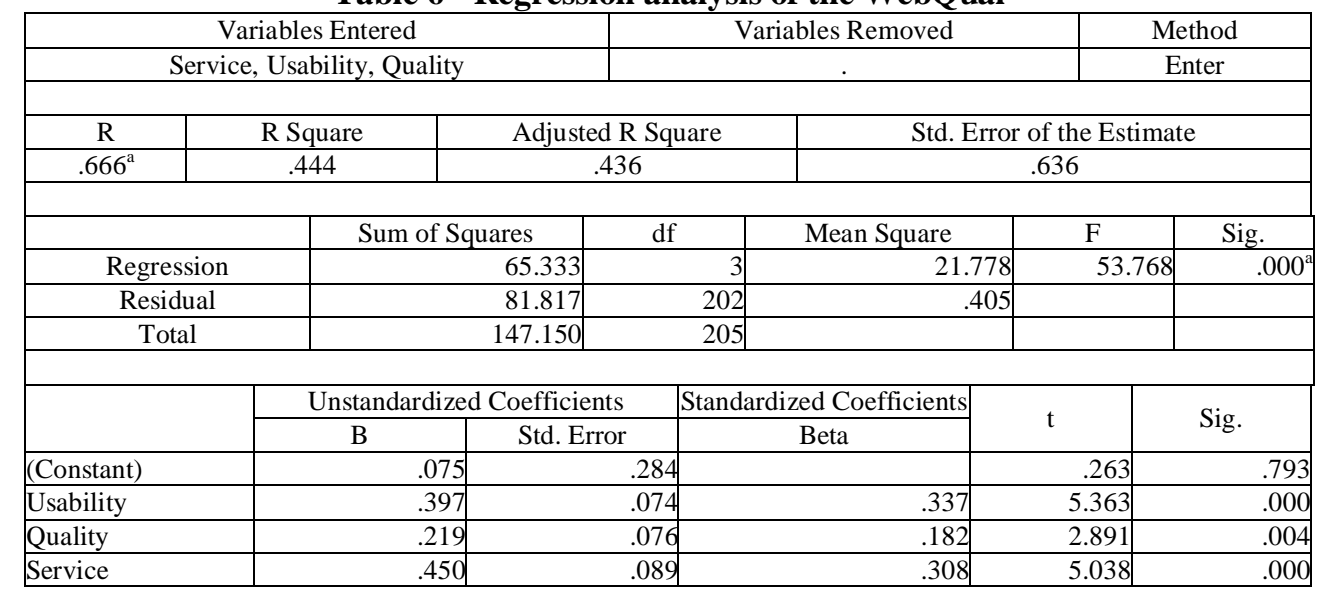

\section{Discussion}

This study looks at the quality requirements of the B-School Websites and tries to develop a model that predicts the user satisfaction in the website. Initially a check list is used to verify the availability of various features in a B-School Website. The results highlight the major features that are found in the Websites and also present an understanding to the website builders a list of features that are required to an academic website to create a user satisfaction. About the institute, Contact details, Admission details, the details of programmes offered, Placement services and application download are basic features that are found in an academic Website.

About the management, Infrastructure details, Courses offered, events and programme, news and diary, publications and Alumni connections are frequently found in academic websites. Location map, Link to learning management systems, Web 2.0 features and feedback system are some of special features that are found in only a few Websites.

This study shows that most of the B-School has their Websites as a static information channel or an information placeholder. The strategic use of website is not being done by many B-Schools. However, a few BSchools websites are being use as a gateway for all the stakeholders like, students, industry, parents, faculty, the administrators and the management. This makes everyone to get into the website for all their information requirements and transactions. The websites being more dynamic, versatile and more users friendly make it a most visited site and provide satisfaction to the users. Apart from the features of a Website the user satisfaction depends on the quality of the Website. Quality is the fitness for purpose. Though a Website may have many features, do the features serve the real purpose they are intended for. Building a Website with huge graphics leaves it slow in loading and annoys the user. However, to be more informative and attractive the Websites need 
to use charts and pictures. Therefore, a balance is required in providing a Website that gives an ultimate satisfaction in terms of both information quality and service quality. The websites were tested with the WebQual- 4 measures to understand the quality level and to what degree the users are satisfied from the use of the Website. The usability factors such as easy to learn, easy to navigate, clear interaction and easy to use are found in more websites. These variables are also found to influence the user satisfaction to a larger extend. The Service interactions such as security, personalization, sense of community are all found to be low in the BSchool websites. However, the influence of these variables are found be more prominent on the user satisfaction. Therefore the Websites should be designed such that they are secure in holding information and users will not hesitate in providing sensitive information. Similarly, instead of building a website on the promoter's perspective, they need to be developed more on the user centric requirements. This will help in providing a personalize feel to the user who visit the Website and also a feeling of belongingness to the BSchool community.

The information quality is also found be good in the B-School websites. This reflects the learned community and their versatility in the messages and effectiveness in communication. However, the influence of these factors on the user satisfaction is found to be significant, its degree is secondary to the usability and Service interaction requirements of the Website. This can interpreted that the B-School websites are expected to provide accurate, timely, accurate, understandable, detailed, well-formatted information and they stand to the expectations and provide them in a better level. Therefore their influence on user satisfaction is found to be obvious but to a lesser extent. The previous studies on user satisfaction on various features of Information Technology (IT) and Information system (IS) like software packages, Internet utilities, technological devices has shown that a satisfied user will utilize the technology more frequently and thereby become more efficient. Therefore the necessities of the user satisfaction in the B-School Websites are important to bring them to the site and make them utilize the various features, so that information is disseminated more effectively and efficiently.

\section{Conclusion}

Understanding the need and importance of a website for a B-School, this study was proposed to survey the various features available in the B-School Website. In addition, the factors that lead to the satisfaction of the user are also studied. With a focus group formed from the students of Post Graduate Business Management programme, the Websites were tested. The findings rank the most prominently found feature and the least found features in a B-School Website. The perceived quality of the Websites were also evaluated and found that usability and the service interaction are the most predicting factors of user satisfaction in the Websites. The information quality is also has a significant influence on the user satisfaction. This study helps the B-Schools and the designers of the B-School Websites to understand the various requirements of a Website, and how to build them with quality such that users visiting the Website are satisfied and visit them frequently.

\section{References}

[1] Carr, N.G. (2003). IT Doesn't Matter. Harvard Business Review, 81(5), 5-12.

[2] Zhang, P. \& Von Dran, G.M.,(2002). User Expectations and Rankings of Quality Factors in Different Website Domains. Proceedings of International Journal of Electronic Commerce, 6 (2), 9-33.

[3] Liang, T.P. \& Lai, H.J. (2002). Effect of store design on consumer purchases: an empirical study of on-line bookstores, Inf. Manage., 39(6), 431-444.

[4] Jati, H., \& Dominic, D.D. (2009). Quality Evaluation of E-government Website Using Web Diagnostic Tools: Asian Case. Information Management and Engineering, 2009 (ICIME '09) Kuala Lumpur, April 3-5, 85 - 89.

[5] Kopcso, D., Pipino, L., \& Rybolt, W. (2001). Factors affecting the assessment of website quality. The 9th European Conference on Information Systems, Bled, Slovenia. 848-853.

[6] Bressolless, G., \& Nantel, J., (2004). Electronic Service Quality: A Comparison of Three Measurements. 33th EMAC Conference, Murcia, Spain. 1-7.

[7] Bressolles, G., \& Nantel, J. (2008). The Measurement of Electronic Service Quality: Improvements and Application. Internati onal Journal of E-Business Research (IJEBR), 4(3) 1-19.

[8] Wolfinbarger, M., \& Gilly, M.C. (2003). eTailQ: dimensionalizing, measuring and predicting etail quality. Journal of retailing. 79, 183-198.

[9] Barnes, S., \& Vidgen, R. T. (2003). Interactive E-Government: Evaluating the Web Site of the UK Inland Revenue. Journal of Electronic Commerce in Organizations, 2(1), 22pp.

[10] Yoo, B., \& Donthu, N. (2001). Developing a scale to measure the perceived quality of a Internet shopping site (SITEQUAL). Quarterly Journal of Electronic commerce, 2(1), 31-47.

[11] Bressolles, G. (2006), "Electronic service quality: NetQual-Proposition of a measurement scale to commercial Web sites and moderating effects, Recherche et Applications en Marketing, 21 (3), 19-45.

[12] Loiacono, E.T., Watson, R.T. \& Goodhue, D.L. (2002). WebQual: a measure of Web site quality. Proceedings of the AMA Winter Educators' Conference, American Marketing Association, Chicago, IL, 432-440.

[13] Kim, E.B. \& Eom, S.B. (2002). Designing effective cyber store user interface. Industrial Management and Data Systems, 102 (5), 241-251. 
[14] Barnes, S.J. \& Vidgen, R.T. (2001a). Assessing the Quality of Auction Web Sites. Proceedings of the Hawaii International Conference on Systems Sciences. Maui, Hawaii, January 4-6, 2001.

[15] Barnes, S.J. \& Vidgen, R.T. (2000).WebQual: An Exploration of Web Site Quality,. Proceedings of the Eighth European Conference on Information Systems, Vienna, July 3-5, 1, 298-305.

[16] Gullikson, S., Ruth Blades, Bragdon, M., McKibbon, S., Sparling, M., \& Toms, E.G. (1999). The impact of information architecture on academic web site usability. The Electronic Library, 17(5), 293-304.

[17] Tate, M., Evermann, J., Hope, B., \& Barnes, S. (2007). Perceived Service Quality in a University Web Portal: Revising the E-Qual Instrument. 40th Annual Hawaii International Conference on System Sciences (HICSS'07), 147b.

[18] Barnes, S.J. \& Vidgen, R.T. (2001b). An Evaluation of Cyber-Bookshops: The WebQual Method. International Journal of Electronic Commerce, 6 (1), 253-265.

[19] Thelwall, M. (2000). Effective websites for small and medium-sized enterprises. Journal of Small Business and Enterprise Development, 7(2), $149-159$.

[20] Barnes, S.J. \& Vidgen, R.T. (2001c). Assessing the Effect of a Web Site Redesign Initiative: An SME Case Study. International Journal of Management Literature, 1, 113-126.

[21] Barnes, S., \& Vidgen, R.T (2002). An Integrative Approach to the Assessment Of E-Commerce Quality. Journal of Electronic Commerce Research, 3(3), 114-127.

[22] Shchiglik, C., Barnes, S.J., \& Vidgen, R.T. (2003). Assessing customers perceived website quality: an airline industry perspective. Australasian Conference on Information Systems, Perth.

[23] Alanezi, M.A., Kamil, A., \& Basri, S. (2010). A proposed instrument dimensions for measuring e-government service quality. International Journal of u- and e- Service, Science and Technology, 3(4), 1-18.

[24] Longstreet, P. (2010). Evaluating Website Quality: Applying Cue Utilization Theory to WebQual. Proceedings of the 43rd Hawaii International Conference on System Sciences (HICSS '10), 1-7.

[25] Loiacono, E. T., Chen, D. Q., \& Goodhue, D. L. (2002). WebQualTM revisited: predicting the intent to reuse a website. Eighth Americas Conference on Information Systems on the World Wide Web. [Online]. Available WWW: http://www.terry.uga.edu/people/dchen/AMCIS2002.pdf. [Accessed 13 Febraury 2011].

[26] Gehrke, D., \& Turban, E. (1999). Determinants of Successful Website Design: Relative Importance and Recommendations for Effectiveness. Proceedings of the 32nd Hawaii International Conference on System Sciences - (HICSS1999), Maui, Hawaii, USA.

[27] Carlson, J., Voola, R., \& Sinnapan, S. (2003). Application of the WebQualTM instrument to three Australian B2C websites: an exploratory investigation. ANZMAC 2003 Conference Proceedings Adelaide 1-3 December 2003, 1734- 1741.

[28] Long, M., \& McMellon, C. (2004). Exploring the determinants of retail service quality on the Internet. Journal of Services Marketing, 18(1), 78-90.

[29] Webb, H.W., \& Webb, L.A. (2004). SiteQual: an integrated measure of Web site Quality. The Journal of Enterprise Information Management, 17(6), 430-440.

[30] Sigala M, \& Christou, E. (2006) Investigating the impact of e-customer relationship management on hotels 'website service quality. In, Ljungberg, J., \&Andersson, M. (Eds.), Proceedings of the Fourteenth European Conference on Information Systems, Goteborg, 1974-1986.

[31] Durova, D.A., \& Amin, N. (2009). Using WebQual 4.0 in the Evaluation of the Russian B2C Cosmetic Web Sites. WEBIST 2009 Proceedings of the Fifth International Conference on Web Information Systems and Technologies, Lisbon, Portugal, March 23-26, 585-588.

[32] Tarigan, J. (2008). User Satisfaction Using Webqual Instrument: A Research on Stock Exchange of Thailand (SET). Jurnal Akuntansi dan Keuangan, 10(1), $24-47$.

[33] Fotakis, Th. \& Economides, A. A. (2008). Art, science/ technology and history museums on the web. International Journal on Digital Culture and Electronic Tourism. 1(1), 37-63.

[34] Arientawati. (2010) Comparison of internet banking Website quality between two bank using WebQual 4.0 Unpublished Thesis of University Gunadarma, Jakarta, Indonesia.

[35] Barnes, S., Liu, K., \& Vidgen, R.T (2001), Evaluating WAP News Sites, The Webqual/M Approach. The 9th European Conference on Information Systems. Bled, Slovenia, June 27-29, 2001.

[36] Fink, D., \& Nyaga, C. (2009). Evaluating web site quality: the value of a multi paradigm approach. Benchmarking: An International Journal, 16(2), 259-273.

[37] Bauer, C., \& Scharl, A. (2000) Quantitive evaluation of Web site content and structure. Internet Research, 10(1), 31-43.

[38] Nusair, K., \& Kandampully, J. (2008). The antecedents of customer satisfaction with online travel services: a conceptual model. European Business Review, 20(1), 4-19.

[39] Huang, W., Le, T., Li, X., \& Gandha, S. (2006). Categorizing web features and functions to evaluate commercial web sites: An assessment framework and an empirical investigation of Australian companies. Industrial Management \& Data Systems, 106(4), 523-539.

[40] Kim, M., \& Stoel, L. (2004). Apparel retailers: Web site quality dimensions and satisfaction. Journal of Retailing and Consumer Services, (2004), 11, 109-117.

[41] Kim, S., \& Lee, Y. (2006). Global online marketplace: a cross-cultural comparison of website quality. International Journal of Consumer Studies, 30(6), 533-543.

[42] García, M.V., Rivero, A.J.L., Aguilar, L.J., \& Enríquez, J.M.L. (2005). A study on the applicability of online service quality models in testing e-loyalty. Proceedings of the IADIS International Conference on WWW/Internet-2005, 60-64.

[43] Barnes, S., \& Vidgen, R.T. (2005). Data Triangulation in action: using comment analysis to refine web quality metrics. In: Proceedings of the 13 th European Conference on Information Systems, Regensburg, Germany, May 26-28.

[44] Bailey, J. E., \& Pearson, S. W. (1983). Development of a Tool for Measuring and Analyzing User Satisfaction. Management Science, 29(5), 530-545.

[45] Strong, D. M., Lee, Y. W., \& Wang, R. Y., (1997). Data quality in context. Communications of the ACM, 40(5), 103-110. 
[46] Wang, R.Y (1998). A Product Perspective on Total Data Quality Management,. Communications of the ACM, 41 (2), 5865.Parasuraman, A. (1995). Measuring and Monitoring Service Quality. William Glynn \& James Barnes (Eds.), Understanding Services Management, Wiley, Chichester.

[47] Zeithaml, V., Parasuraman, A., \& Berry, L. (1990). Delivering Quality Service: balancing customer perceptions and expectations. New York: The Free Press.

[48] Pitt, L., Watson, R., \& Kavan, C. (1995). Service Quality: A Measure of Information Systems Effectiveness. MIS Quarterly, 19, 173-187.

[49] Pitt, L., Watson, R. \& Kavan, C. (1997). Measuring Information Systems Service Quality: Concerns for a Complete Canvas. MIS Quarterly, 21, 209-221.

[50] Kettinger, W., \& Lee, C. (1997). Pragmatic Perspectives on the Measurement of Information Systems Service Quality. MIS Quarterly, 21, 223-240.Van Dyke, T., Kappelman, L., \& Prybutok, V. (1997). .Measuring Information Systems Service Quality: Concerns on the Use of the SERVQUAL questionnaire. MIS Quarterly, 21, 195-208.

[51] Shostack, G. (1985). Planning the Service Encounter. Czepiel, J., Solomon, M. \& Surprenant, C. (Eds.), The Service Encounter, Lexington Books, Lexington, MA.

[52] Davis, F.D. (1989). Perceived Usefulness, Perceived Ease of Use and User Acceptance of Information Technology. MIS Quarterly. 13(3), 319-339.

[53] Davis, F. D. (1993). User Acceptance of Information Technology: System Characteristics, User Perceptions, and Behavioral Impacts,. International Journal of Man-Machine Studies, 38, 475-487.

[54] Nielsen, J. (1993). Usability Engineering. Morgan Kaufmann: San Francisco.

[55] Nielsen, J., (1999).User Interface Directions for the Web,. Communications of the ACM, 42(1), 65-72.

[56] Nielsen, J. (2000). Designing Web Usability. New Riders Publishing: Indiana.

[57] Spool, J., Scanlon, T., Schroeder, W., Snyde,r C. \& DeAngelo, T. (1999). Web Site Usability: a Designer's Guide, Morgan Kaufmann, San Francisco.

[58] Boudreau MC, Gefen D and Straub DW (2001). Validation in IS research: A state-of-the-art assessment. MIS Quarterly. 25 (1): 116.

ANNEXURE - I

WEB SITE CONTENTS CHECK LIST

\begin{tabular}{|l|l|}
\hline ReferencesName of the B-School & \\
\hline URL & \\
\hline Google search by Name (Number of total results) & \\
\hline
\end{tabular}

\begin{tabular}{|c|c|c|}
\hline 1 & About the institute & $\square$ \\
\hline 2 & About the Management & $\square$ \\
\hline 3 & Location Map & $\square$ \\
\hline 4 & Infrastructure details & $\square$ \\
\hline 5 & Details of office and services & $\square$ \\
\hline 6 & Departments & $\square$ \\
\hline 7 & Program & $\square$ \\
\hline 8 & Curriculum & $\square$ \\
\hline 9 & Courses & $\square$ \\
\hline 10 & Admission details & $\square$ \\
\hline 11 & Application download & $\square$ \\
\hline 12 & Faculty directory & $\square$ \\
\hline 13 & Staff Directory & $\square$ \\
\hline 14 & Link to library resources & $\square$ \\
\hline 15 & Link to Learning management system (LMS like Moodle) & $\square$ \\
\hline 16 & Examination and results & $\square$ \\
\hline 17 & Research centre & $\square$ \\
\hline 18 & Publications & $\square$ \\
\hline 19 & Students community & $\square$ \\
\hline 20 & Alumni connection & $\square$ \\
\hline 21 & News and diary & $\square$ \\
\hline 22 & Events and programmes & $\square$ \\
\hline 23 & Academic calendar & $\square$ \\
\hline 24 & Life at campus & $\square$ \\
\hline 25 & Industry Connect & $\square$ \\
\hline 26 & Placement & $\square$ \\
\hline 27 & Repository (Lecture notes, Presentations, Podcast, Video, etc.) & $\square$ \\
\hline 28 & Accreditation information & $\square$ \\
\hline 29 & Web 2.0 features (Blog, social networking etc) & $\square$ \\
\hline 30 & Mail service & $\square$ \\
\hline 31 & Search engine & $\square$ \\
\hline 32 & Site Map & $\square$ \\
\hline 33 & Contact details & $\square$ \\
\hline 34 & Feedback system & $\square$ \\
\hline
\end{tabular}


ANNEXURE - II

THE WEBQUAL 4.0 INSTRUMENT

\begin{tabular}{|c|c|c|c|c|c|c|}
\hline & & 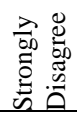 & 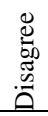 & 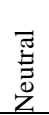 & 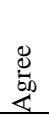 & 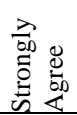 \\
\hline \multicolumn{7}{|c|}{ Usability } \\
\hline 1 & I find the site easy to learn to operate & & & & & \\
\hline 2 & My interaction with the site is clear and understandable & & & & & \\
\hline 3 & I find the site easy to navigate & & & & & \\
\hline 4 & I find the site easy to use & & & & & \\
\hline 5 & The site has an attractive appearance & & & & & \\
\hline 6 & The design is appropriate to the type of site & & & & & \\
\hline 7 & The site conveys a sense of competency & & & & & \\
\hline 8 & The site creates a positive experience for me & & & & & \\
\hline \multicolumn{7}{|c|}{ Information quality } \\
\hline 9 & Provides accurate information & & & & & \\
\hline 10 & Provides believable information & & & & & \\
\hline 11 & Provides timely information & & & & & \\
\hline 12 & Provides relevant information & & & & & \\
\hline 13 & Provides easy to understand information & & & & & \\
\hline 14 & Provides information at the right level of detail & & & & & \\
\hline 15 & Presents the information in an appropriate format & & & & & \\
\hline \multicolumn{7}{|c|}{ Service interaction } \\
\hline 16 & Any personal information is secure & & & & & \\
\hline 17 & Creates a sense of personalization & & & & & \\
\hline 18 & Convey s a sense of community & & & & & \\
\hline 19 & Makes it easy to communicate with the organization & & & & & \\
\hline 20 & The web page loads faster & & & & & \\
\hline 21 & Website is compatibility with all platform & & & & & \\
\hline \multicolumn{7}{|c|}{ Overall } \\
\hline 22 & As a whole I am satisfied with the website & & & & & \\
\hline
\end{tabular}

\section{BIOGRAPHY}

Elangovan. $\mathrm{N}$ is an assistant professor at Department of Management Studies, Christ University, Bangalore. He holds a B.E. degree in Mechanical Engineering and an MBA Degree with specialization in Marketing. He has also received M.Sc. and M.Phil. degrees in Psychology. His primary teaching interest is in Marketing and Information Systems. His area of interest and research is in strategic information systems management. 